\title{
Environmental parameters and diversity of diatoms in the Aïn Dalia dam, Northeast of Algeria
}

\author{
KARIMA HERAMZA ${ }^{1,2, \bullet}$, CHOUKRI BAROUR ${ }^{3}$, AICHA DJABOURABI ${ }^{2}$, WILLIA KHATI ${ }^{1}$, \\ CHAHINAISE BOUALLAG ${ }^{2, \vee \varphi}$ \\ ${ }^{1}$ Laboratory of Biodiversity and Pollution of Ecosystems. Faculty of Science of Nature and Life, Chadli Bendjedid University. El Tarf, 36000, Algeria. \\ "email: heremza_karima@yahoo.com. \\ ${ }^{2}$ Laboratory of Ecobiology of Marine and Littoral Environments. Faculty of Sciences, Badji Mokhtar University. Annaba, PB. 12, Annaba. 23000, \\ Algeria. "vemail: c.boualleg@univ-soukahras.dz. \\ ${ }^{3}$ Laboratory of Aquatic and Terrestrial Ecosystems, Faculty of Natural and Life Sciences, Mohamed Cherif Messaadia University. Souk Ahras, PB 1553,
} 41000 Souk Ahras, Algeria

Manuscript received: 7 May 2021. Revision accepted: 1 August 2021.

\begin{abstract}
Heramza K, Barour C, Djabourabi A, Khati W, Bouallag C. 2021. Environmental parameters and diversity of diatoms in the Aïn Dalia dam, Northeast of Algeria. Biodiversitas 22: 3633-3644. Diatoms have long been used as biological indicators of the quality of aquatic environments due to their important capacity to respond to environmental change. As this flora has been very little studied in Algeria, the present study aimed to monitor the Spatio-temporal dynamics of diatoms at the Ain Dalia dam (north-eastern of Algeria) and determine the main abiotic factors contributing to these variations from June 2017 to May 2018 in four selected stations. Our results showed that the waters of Aïn Dalia dam waters vary from moderately (St1 and St3) to significantly polluted (St2 and St4). They host the community of planktonic diatom flora composed of 72 species. The interspecific biodiversity was marked in summer and autumn (57 and 56 species respectively) and in the St4 station (52 species). In terms of abundance, more than $40 \%$ of the overall density was found in the St 4 station and the fall period. Among the dominant genera, Cyclotella, Thalassiosira, Synedra and Navicula are found in moderately polluted waters, while Nitzschia, Melosira and Surirella in significantly polluted waters. Some environmental parameters, including nutrients $\left(\mathrm{PO}_{4}{ }^{3-}\right.$ and $\left.\mathrm{NO}_{2}{ }^{-}\right)$, SM, temperature, dissolved oxygen, and $\mathrm{pH}$ played a key role in the functioning and evolution of this lake. Hence, these parameters demonstrated important fluctuations during our study and influenced directly the diatom distribution. These results showed that diatom assemblages are influenced by anthropogenic disturbances, and can be used as indicators of environmental quality.
\end{abstract}

Keywords: Bacillariophyceae, biodiversity, freshwater, physicochemical parameters, water quality

\section{INTRODUCTION}

Diatom communities respond directly to physical and chemical changes in the environment. Previous studies conducted on the diatom ecology have shown that the community structure depends on many factors, including organic matter (Sládeček 1986), pH (Renberg and Hellberg 1982; Zampella et al. 2007), nutrients (Kelly 1998; Pan et al. 1996), depth and water temperature (Afonina et al. 2020). Furthermore, a large diversity of ecological preferences between species results in structural changes in the diatom community. Also, the relatively short generation time makes diatoms rapidly respond to environmental changes, and consequently provide an early signal in the event of pollution (McCormick and Stevenson 1998).

The composition and distribution of aquatic organisms are usually determined by the spatio-temporal dynamics of the environment. In the biotopes different in hydrological and physic-chemical parameters, the plankton communities differ in species composition and abundance (Skála 2015; Voutilainen et al. 2016). Diatoms are used to track the effect of climate (Ruhland et al. 2008) and nutrient enrichment (Hall and Smol 2010). They also often dominate the algal communities in many freshwater systems. Although the ecological importance of diatoms, they were rarely studied in Algeria. These studies were mainly conducted on the continental diatoms of Algeria Baudrimont (1973), and the assemblages of the diatoms in Algerian wadi (Ounissi and Frehi 1999; Al-Asadi et al. 2006; Lange-Bertalot et al. 2009; Chaïb et al. 2011; Chaïb and Tison-Rosebery 2012; Hamaidi-Chergui et al. 2013; Djabourabi et al. 2014; Nehar et al. 2014; Nehar 2016; Draredja 2019; Draredja et al. 2019a,b; Chabaca et al. 2020).

In Algeria, the only study that investigated the ecology of lentic diatoms was undertaken by El Haouati et al. (2015) in Lake Reghaia. In this perspective and to contribute modestly to the enrichment of knowledge on the ecology of the freshwater diatoms, this work aimed to study the environmental factors influencing the diatomic flora of Aïn Dalia reservoir (North-East of Algeria).

Our study is devoted to the diatoms and their spatial and temporal distribution in four selected stations from June 2017 to May 2018. In addition, we identified the diatoms communities and determined the abiotic factors driving their distribution. 


\section{MATERIALS AND METHODS}

\section{Study area}

The Ain Dalia dam is located in the extreme northeastern part of Algeria, $10 \mathrm{~km}$ south of Souk-Ahras city (Table 1). The dam water reservoir has an area of $217 \mathrm{~km}^{2}$ and a total capacity of 82 million $\mathrm{m}^{3}$ (Figure 1). According to the National Agency of Dams and Transfer, the surface water resources are provided mainly by the Wadi (River) of Medjerda which flows from Khemissa region to the Tunisian territory crossing Souk-Ahras city on a length of $113.6 \mathrm{~km}$ (NADT 2013)

\section{Physicochemical measurements, sampling, and treatment of phytoplankton}

A sampling of phytoplankton and measurements of some physicochemical parameters were performed monthly from June 2017 to May 2018 in four selected stations. The geographical position and the characteristics of sampling stations are displayed in Table 1.

Physicochemical measurements (temperature $\left(\mathrm{T},{ }^{\circ} \mathrm{C}\right.$ ), dissolved oxygen $\left.\left(\mathrm{O}_{2}, \mathrm{mg} . \mathrm{L}^{-1}\right), \mathrm{pH}\right)$ were carried out in situ using a multi-parameter analyzer (Consort C561). While nutrients (nitrite, $\mathrm{NO}_{2}{ }^{-}$and orthophosphate, $\mathrm{PO}_{4}{ }^{3-}$ ) were assessed using the spectrophotometers method (Aminot and
Chaussepied 1983). To measure the concentration of suspended matter $(\mathrm{SM})$, a heat-treated $\left(450{ }^{\circ} \mathrm{C}, 30 \mathrm{~min}\right)$ glass fiber filters of $0.45 \mu \mathrm{m}$ nominal porosity $(47 \mathrm{~mm}$ diameter, Whatman GF/CTMTM, Germany) were preweighed and then used for the filtration of the surface water samples. After filtration, the filters were dried at $70{ }^{\circ} \mathrm{C}$ for $48 \mathrm{~h}$. The SM concentration was determined from the difference between the weight of the filter before and after filtration (Aminot and Chaussepied 1983).

Table 1. The geographical coordinates and some characteristics of the study stations

\begin{tabular}{|c|c|c|}
\hline Station & $\begin{array}{c}\text { Geographical } \\
\text { coordinates }\end{array}$ & Characteristics \\
\hline Station 1 & $\begin{array}{l}7^{\circ} 52^{\prime} 52^{\prime \prime} \mathrm{E} \\
36^{\circ} 15^{\prime} 57^{\prime \prime} \mathrm{N}\end{array}$ & Treated water (drinking water) \\
\hline Station 2 & $\begin{array}{l}7^{\circ} 47^{\prime} 50^{\prime \prime} \mathrm{E} \\
36^{\circ} 15^{\prime} 07^{\prime \prime} \mathrm{N}\end{array}$ & $\begin{array}{l}\text { Characterized by the population's } \\
\text { urban waste of sewers, dumps }\end{array}$ \\
\hline Station 3 & $\begin{array}{l}7^{\circ} 49^{\prime} 35^{\prime \prime} \mathrm{E} \\
36^{\circ} 16^{\prime} 06^{\prime \prime} \mathrm{N}\end{array}$ & $\begin{array}{l}\text { Exposed to wind and close to a } \\
\text { zone of intensified agricultural } \\
\text { activity. }\end{array}$ \\
\hline Station 4 & $\begin{array}{l}7^{\circ} 59^{\prime} 48^{\prime \prime} \mathrm{E} \\
36^{\circ} 16^{\prime} 14^{\prime \prime} \mathrm{N}\end{array}$ & $\begin{array}{l}\text { Exposed to wastewater of } \\
\text { treatment station discharge of } \\
\text { Souk-Ahras city. }\end{array}$ \\
\hline
\end{tabular}

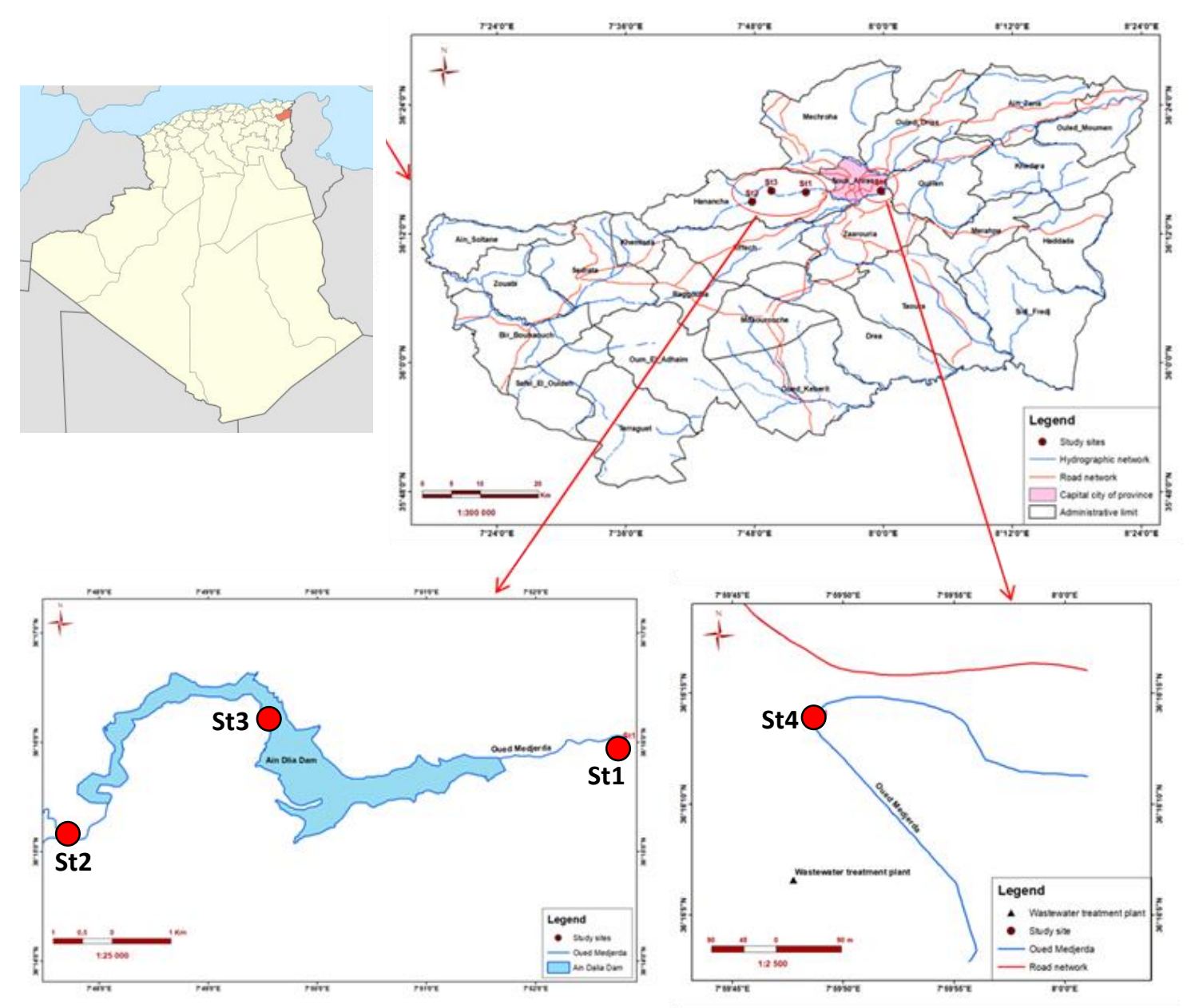

Figure 1. The geographical location of the Ain El-Dalia Dam, Northeast of Algeria and the distribution of the stations. (St1: station 1, St2: station 2, St3: station 3, St4: station 4 
Phytoplankton sampling was performed by filtering the surface water samples using plankton net of $20 \mu \mathrm{m}$ of mesh, and collected samples were fixed immediately with formaldehyde (concentration 10\%). The identification of Diatoms is based on the observation of morpho-anatomical characteristics using a light microscope (Carl Zeiss, Axiostar Plus Microscope) and according to appropriate taxonomic literature like Bourrelly (1985); Loir (2004); Bey and Ector (2013); Peeter and Ector (2017, 2018), whose the taxonomic database "Algae base" was used to standardize the scientific names of diatom taxa. The cell counting was carried out using Nageotte cell counting chamber (Brient et al. 2001). The Diatoms' fauna diversity structure was assessed by calculating the Shannon-Weaver diversity index $\mathrm{H}^{\prime}$ (Shannon and Weaver 1949), the Simpson's diversity index (D) (Simpson 1949), and the Pielou's evenness index J' (Pielou 1975). Additionally, the dominance of the major taxa $(\mathrm{D} \%)$ was determined according to Ngansoumana (2006).

\section{Statistical analyses}

All our statistical analyses were performed using $\mathrm{R}$, version 4.0.1 ( $\mathrm{R}$ Core Team 2020). The Shapiro-Wilk test tested the normality of all variables data. Median differences among seasons and stations were tested by the rank-based nonparametric test of Kruskal Wallis followed by posthoc pairwise comparisons using Dunn's test with Holm's $P$-value adjustment by using the 'Dunn test' package (Dinno 2017). The spatiotemporal variation of our tested biotic and abiotic variables is plotted through many boxplots graphs by using the 'ggplot 2 ' package (Wickham 2016); different lowercase letters indicate a significant difference between the levels of the studied factors. Results are given as means $\pm \mathrm{SD}$ (standard deviation). All the statistical analyses were realized at $\alpha=0.05$ as a significance level.
In addition, the relationships between physicochemical and biological parameters were analyzed by the nonparametric Spearman correlation using 'ggcorrplot' (Kassambara 2019) and 'Hmisc' (Harrell et al. 2020) packages. We carried out also the principal component analysis (PCA) using the 'FactoMineR' (Husson et al. 2020) and 'facto extra (Kassambara and Mundt 2020) packages on standardized data to characterize the spatiotemporal variation of the measured biotic and abiotic variables in Aïn Dalia dam.

\section{RESULTS AND DISCUSSION}

\section{Composition of diatom communities}

The inventory of diatoms resulted of a total of 72 species represented by 17 centric and 55 pennate belonging to 31 genera and 21 families. Six families are the richest in species ( $\mathrm{S}$ : specific richness $\geq 4)$ : Melosiraceae (8 species), Naviculaceae (15 species), Cymbellacea (6 species), Fragilariaceae (7 species), Bacillariaceae (8 species), and Surirellaceae ( 5 species). However, the species richness in the other families' does not exceed 3 species ( $S<4)$ : Asterolampraceae (1 species), Biddulphiaceae (2 species), Heliopeltaceae (2 species), Stephanodiscaceae (2 species), Thalassiosiraceae (4 species), Achnanthaceae (2 species), Catenulaceae (2 species), Rhoicospheniaceae (2 species), Licmophoraceae (1 species), Stauroneidaceae (1 species), Entomoneidaceae (2 species) Rhopalodiaceae (1 species), Amphipleuraceae (1 species), Pinnulariaceae (1 species), Eunotiaceae (1 species) (Table 2).

The dominance index (D) estimation of the 31 identified genera, revealed the dominance of Cyclotella $(\mathrm{D}=18.97 \%)$, Melosira $(\mathrm{D}=13.30 \%)$, Thalassiosira $(\mathrm{D}=$ $13.07 \%)$, Nitzschia $(\mathrm{D}=8.51 \%)$, Navicula $(\mathrm{D}=8.14 \%)$ Surerilla $(\mathrm{D}=5.38 \%)$ and Synedra $(\mathrm{D}=5.34 \%)$. The other genera are secondary taxa $(\mathrm{D}<5 \%)$ (Table 2$)$.

Table 2. Checklist of diatom species identified in Aïn Dalia dam, Algeria (June 2017-May 2018)

\begin{tabular}{|c|c|c|c|}
\hline Family & Genus & & Species \\
\hline \multicolumn{4}{|l|}{ Centric } \\
\hline Asterolampraceae Smith 1872 & Asteromphalus Ehrenberg 1844 & $\mathrm{~S}$ & Asteromphalus sp. \\
\hline \multirow{2}{*}{ Biddulphiaceae Kützing 1844} & Biddulphia Gray 1821 & $\mathrm{~S}$ & Biddulphia sp.1 \\
\hline & & & Biddulphia sp.2 \\
\hline \multirow[t]{2}{*}{ Heliopeltaceae Smith 1872} & Actinoptychus Ehrenberg 1843 & $\mathrm{~S}$ & Actinoptychus sp.1 \\
\hline & & & Actinoptychus sp.2 \\
\hline \multirow[t]{9}{*}{ Melosiraceae Kützing 1844} & Aulacoseira Thwaites 1848 & $\mathrm{~S}$ & Aulacoseira sp. \\
\hline & Hyalodiscus Ehrenberg 1845 & $\mathrm{~S}$ & Hyalodiscus sp. \\
\hline & Melosira C. Agardh 1824 & $\mathrm{D}$ & M. arenaria D.Moore ex Ralfs 1843 \\
\hline & & & M. distans (Ehrenberg), Kützing 1844 \\
\hline & & & M. moniliformis C. Agardh 1824 \\
\hline & & & M. nummuloides C. Agardh 1824 \\
\hline & & & M. undulata (Ehrenberg), Kützing \\
\hline & & & 1844 \\
\hline & & & M. varians C. Agardh 1827 \\
\hline \multirow{4}{*}{$\begin{array}{l}\text { Stephanodiscaceae Glezer \& Makarova } \\
1986 \\
\text { Thalassiosiraceae M. Lebour } 1930\end{array}$} & Cyclotella (Kützing) Brébisson 1838 & $\mathrm{D}$ & C. ocellata Pantocsek 1901 \\
\hline & & & C. parforata Héribaud 1903 \\
\hline & Thalassiosira Cleve 1873 & $\mathrm{D}$ & T. rotula Meunier 1910 \\
\hline & & & Thalassiosira sp. \\
\hline
\end{tabular}




\begin{tabular}{|c|c|c|c|}
\hline \multicolumn{4}{|l|}{ Penate: complete absence of raphe } \\
\hline \multirow[t]{7}{*}{ Fragilariaceae Kützing 1844} & Fragilaria Lyngbye 1819 & $\mathrm{~S}$ & Fragilaria sp. \\
\hline & & & F. capucina Desmazières 1830 \\
\hline & Meridion C. Agardh 1824 & $\mathrm{~S}$ & $\begin{array}{l}\text { M. circulare (Greville) C.Agardh } \\
1831\end{array}$ \\
\hline & Synedra Ehrenberg 1830 & $\mathrm{D}$ & S. acus Kützing 1844 \\
\hline & & & S. ulna Kützing 1844 \\
\hline & & & Synedra sp. 1 \\
\hline & & & Synedra sp.2 \\
\hline Licmophoraceae Kützing 1844 & Licmophora C. Agardh 1827 & S & Licmophora sp. \\
\hline \multicolumn{4}{|l|}{ Penate: presence of raphe } \\
\hline \multirow[t]{2}{*}{ Achnanthaceae Kützing 1844} & Cocconeis Ehrenberg 1836 & $S$ & Cocconeis sp. \\
\hline & & & Cocconeis placentula Ehrenberg 1838 \\
\hline Rhoicospheniaceae Topachevs'kyj \& & Rhoicosphenia (Kützing) Grunow & $\mathrm{S}$ & Rhoicosphenia sp. \\
\hline Oksiyuk 1960 & 1860 & & \\
\hline \multirow[t]{3}{*}{ Catenulaceae Mereschkowsky 1902} & Amphora Ehrenberg ex Kützing, & $S$ & A. cummutata Grunow 1880 \\
\hline & 1844 & & A. hyalina Kützing 1844 \\
\hline & & & Amphora holsatica Hustedt 1925 \\
\hline \multirow[t]{7}{*}{ Cymbellaceae Kützing 1844} & Cymbella C. Agardh 1830 & $\mathrm{~S}$ & C. aspera (Ehrenberg) Cleve 1894 \\
\hline & & & C. parva (W.Smith) Kirchner 1878 \\
\hline & & & C. tumida (Brébisson) Van Heurck \\
\hline & & & 1880 \\
\hline & & & C. turgidula Grunow 1875 \\
\hline & & & Cymbella sp.1 \\
\hline & & & Cymbella sp.1 \\
\hline Entomoneidaceae Reimer in Patrick \& & Amphiprora Ehrenberg 1843 & $\mathrm{~S}$ & A. alata (Ehrenberg) Kützing 1844 \\
\hline Reimer 1975 & & & A. paludosa W.Smith 1853 \\
\hline $\begin{array}{l}\text { Rhopalodiaceae (Karsten) Topachevs'kyj } \\
\& \text { Oksiyuk } 1960\end{array}$ & Epithemia Kützing 1844 & $\mathrm{~S}$ & Epithemia sp. \\
\hline Eunotiaceae Kützing 1844 & Eunotia Ehrenberg 1837 & $\mathrm{~S}$ & $\begin{array}{l}\text { E. pectinalis (Kützing) Rabenhorst } \\
1864\end{array}$ \\
\hline Stauroneidaceae D.G. Mann & Craticula Grunow 1868 & S & C. cuspidata (Kutzing) DGMann 1990 \\
\hline Amphipleuraceae Grunow 1862 & Frustulia Rabenhorst 1853 & S & F. vulgaris (Thwaites) De Toni 1891 \\
\hline \multirow[t]{16}{*}{ Naviculaceae Kützing, 1844} & Caloneis Cleve 1894 & S & Caloneis sp. \\
\hline & Gomphonema C. Agardh 1824 & $S$ & G. italicum Kützing 1844 \\
\hline & & & G. parvulum (Kützing) Kützing 1849 \\
\hline & & & Gomphonema sp.1 \\
\hline & & & Gomphonema sp.2 \\
\hline & Gyrosigma Hassall 1845 & $\mathrm{~S}$ & G. fasciola (Ehrenberg) J.W. Griffith \\
\hline & & & \& Henfrey 1856 \\
\hline & & & G. hippocampus Hassall 1845 \\
\hline & Navicula Bory 1822 & $\mathrm{D}$ & N. abrupta (W.Gregory) Donkin 1870 \\
\hline & & & N. gregaria Donkin 1861 \\
\hline & & & N. radiosa Kützing 1844 \\
\hline & & & N. salinarum Grunow 1880 \\
\hline & & & N. tripunctata (O.F.Müller) Bory 1822 \\
\hline & & & N. trivialis Lange-Bertalot 1980 \\
\hline & & & Navicula sp.1 \\
\hline & & & Navicula sp. 2 \\
\hline Pinnulariaceae D.G.Mann & Pinnularia Ehrenberg 1843 & S & Pinnularia sp. \\
\hline \multirow[t]{8}{*}{ Bacillariaceae Ehrenberg 1831} & Bacillaria JF Gmelin 1791 & S & $\begin{array}{l}\text { B. paradoxa JFGmelin in Linnaeus } \\
1791\end{array}$ \\
\hline & Hantzschia Grunow 1877 & $\mathrm{~S}$ & $\begin{array}{l}\text { H. omphioxys (Ehrenberg) Grunow } \\
1880\end{array}$ \\
\hline & Nitzschia Hassal 1845 & $\mathrm{D}$ & N. brevissima Grunow 1880 \\
\hline & & & N. longissima (Brébisson) Ralfs 1861 \\
\hline & & & N. reversa W.Smith 1853 \\
\hline & & & N. segmoidea (Nitzch) W.Smith 1853 \\
\hline & & & Nitzschia sp.1 \\
\hline & & & Nitzschia sp.2 \\
\hline \multirow[t]{5}{*}{ Surirellaceae Kützing 1844} & Cymatopleura W.Smith 1851 & S & C. elliptica (Brébisson) W.Smith 1851 \\
\hline & & & C. solea (Brébisson) W.Smith 1851 \\
\hline & Surirella Turpin 1828 & $\mathrm{D}$ & S. gemma (Ehrenberg) Kützing 1844 \\
\hline & & & S. ovalis Brébisson 1838 \\
\hline & & & S. robusta Ehrenberg 1841 \\
\hline
\end{tabular}

Note: D: Dominant (D $\geq 5 \%)$, S: Secondary ( $<<5 \%$ (Ngansoumana 2006) 


\section{Seasonal and spatial distribution of diatoms}

In terms of proportions in relation to the overall density of the diatoms collected, the diatoms show seasonal densities that evolve in decreasing order according to autumn $(43 \%) \geq$ Winter $(25 \%) \geq$ Summer $(18 \%) \geq$ Spring $(14 \%)$. Furthermore, the highest proportions are found in St4 (44\%) compared to $20 \%, 19 \%$, and $17 \%$ respectively in St3, St2, and St1 (Figure 2).

\section{Seasonal distribution of dominant genera}

Among the dominant genera, those that predominate in terms of abundance are Melosira, Cyclotella and Nitzschia in autumn (72\% of seasonal density), Thalassiosira, Cyclotella and Synedra in spring (80\%), Navicula, Nitzschia and Thalassiosira in summer (66\%) and Cyclotella, Thalassiosira and Melosira in winter (77\%) (Figure 3).

\section{Spatial distribution of dominant genera}

Among the 7 dominant genera, we note, in stations St1, St2 and St3, the predominance of Cyclotella and Thalassiosira, which together account for $64 \%, 58 \%$ and $57 \%$ respectively; in station St 4 , the predominant genera are Melosira and Surirella (35 and 18\% respectively) (Figure 4).

\section{Ecological indices}

Diatoms species, diversity and evenness indices per season and station are shown in Table 3. The maximum richness was observed in autumn $\left(\mathrm{S}=57\right.$ species, $\mathrm{H}^{\prime}=3$, $\mathrm{D}=0.926, \mathrm{E}=0.742)$ and summer, $\left(\mathrm{S}=56\right.$ species, $\mathrm{H}^{\prime}=2.999$, $\mathrm{D}=0.926, \mathrm{E}=0.742$ ). Regarding spatial specific richness, the highest values of ecological indices are recorded in station St4 ( $\mathrm{S}=52$ species; $\mathrm{H}^{\prime}=3$ and $\left.\mathrm{D}=0.926 ; \mathrm{E}>0.761\right)$ (Table 3).

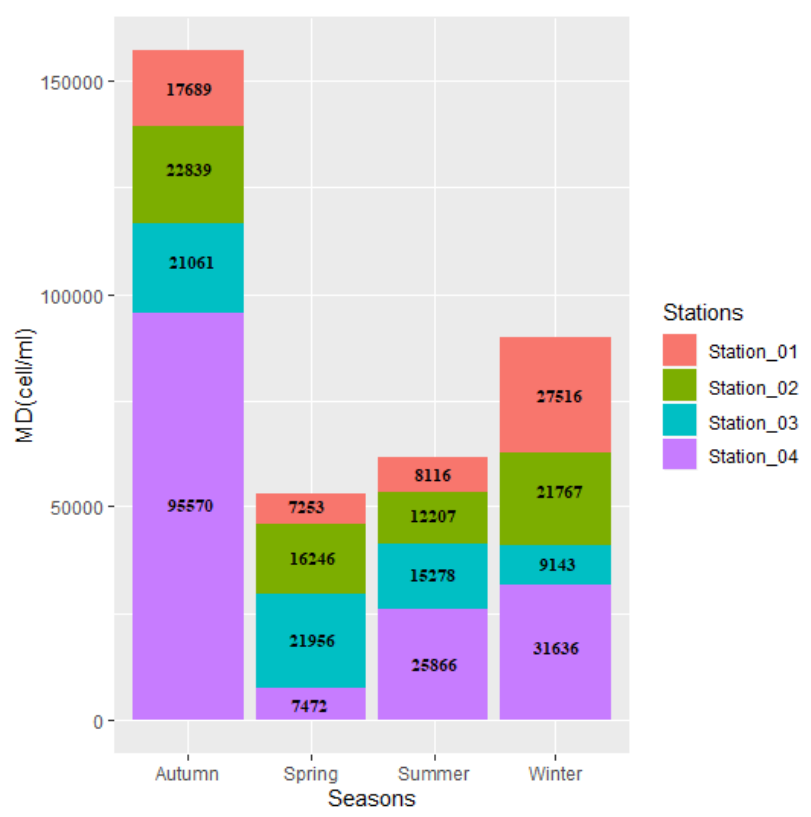

Figure 2. Spatio-temporal distribution of diatom densities (MD) (June 2017-May 2018).

\section{Statistical analyses}

Physicochemical characterization of Aïn Dalia Dam's water

The spatial and temporal variations of the physicochemical parameters of the waters of Aïn Dalia are shown in Table 4.

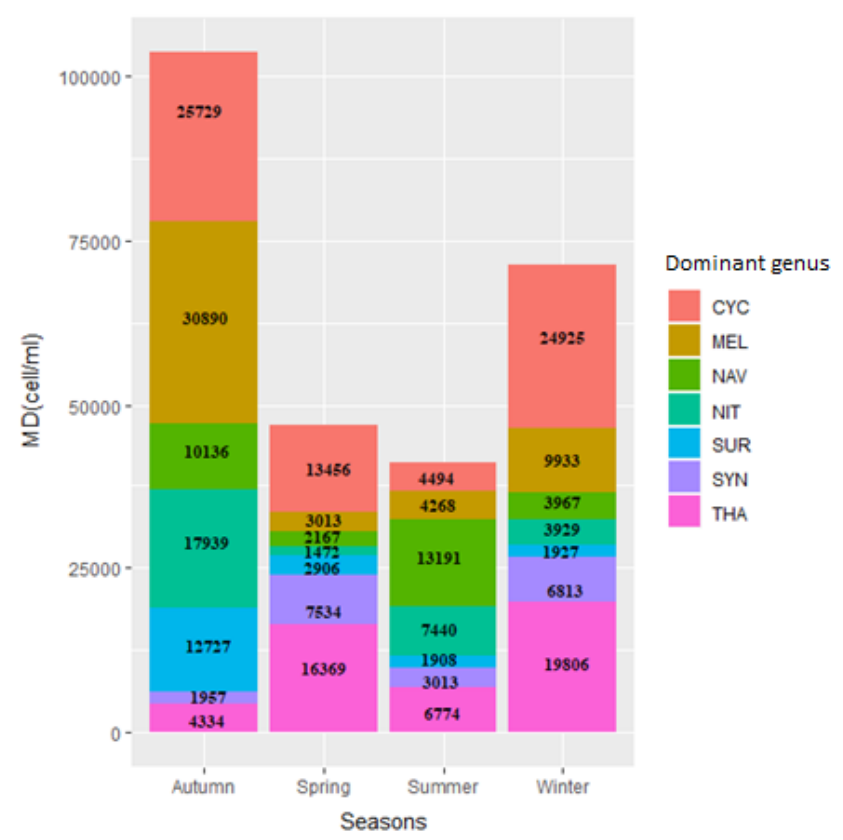

Figure 3. Seasonal distribution of dominant genus (June 2017May 2018). Note: CYC: Cyclotella, MEL: Melosira, NAV: Navicula, NIT: Nitzschia, SUR: Surirella, SYN: Synedra, THA: Thalassiosira

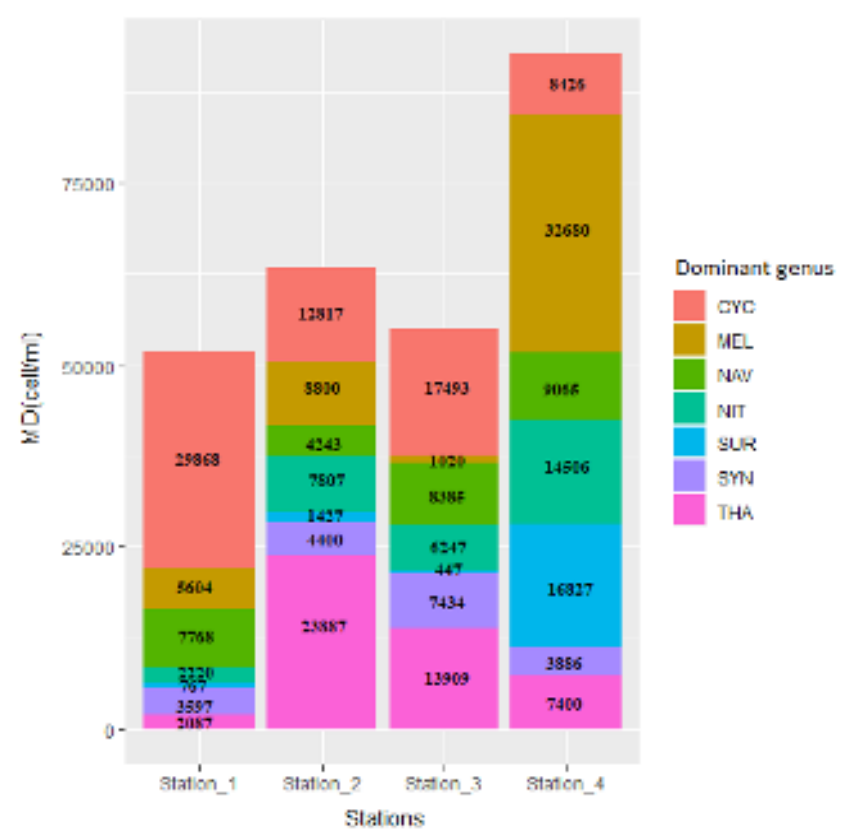

Figure 4. Spatial distribution of the dominant genus (June 2017May 2018). Note: CYC: Cyclotella, MEL: Melosira, NAV: Navicula, NIT: Nitzschia, SUR: Surirella, SYN: Synedra, THA: Thalassiosira 
Table 3. Spatio-temporal evolution of ecological indices of diatoms enumerated (June 2017-May 2018)

\begin{tabular}{llcccc}
\hline \multicolumn{7}{c}{ Ecological index } & & \\
\hline \multirow{5}{*}{ Season } & & S & H' & D & E \\
& Summer & 56 & 2.996 & 0.921 & 0.744 \\
& Autumn & 57 & 2.999 & 0.924 & 0.742 \\
& Winter & 43 & 2.586 & 0.874 & 0.687 \\
& Spring & 36 & 2.231 & 0.810 & 0.623 \\
\multirow{5}{*}{ Station } & & & & & \\
& St1 & 44 & 2.503 & 0.826 & 0.662 \\
& St2 & 49 & 2.618 & 0.865 & 0.673 \\
& St3 & 45 & 2,362 & 0.889 & 0.683 \\
& St4 & 52 & 3.007 & 0.926 & 0.761 \\
\hline
\end{tabular}

- Note: S: specific richness, H': Shannon-Weaver index, D: Simpson index, E: Regularity index

The difference in $\mathrm{T}$ between stations is only $3{ }^{\circ} \mathrm{C}$; however, the difference is about $14^{\circ} \mathrm{C}$ between winter $\left(10.73^{\circ} \mathrm{C}\right)$ and summer $\left(24.86^{\circ} \mathrm{C}\right)$, with intermediate values in autumn and spring. The $\mathrm{pH}$ of the Dam's water is alkaline $(\geq 7.5)$; high values are recorded in spring (7.99) and at the St3 (7.89) and low values (7.56) in winter and at the St2. The $\mathrm{O}_{2}$ saturation levels ranged from 34 to $73 \%$; minimums (close to $34.5 \%$ ) are recorded in summer and in St2 and maximums in winter $(66.46 \%)$ and in St1 $(73.71 \%)$. The lowest SM concentrations are noted at St1 and St3 (25 and 53 g. $\mathrm{L}^{-1}$, respectively) and the highest at St2 and St4 (139 and 158 g.L L $^{-1}$, respectively). Excepting winter, when SM levels reached 160 g.L $\mathrm{L}^{-1}$, the values in the other seasons fluctuated between 61 and 79 g.L. ${ }^{-1}$.

Furthermore, in winter and at St1 the orthophosphate levels showed values that are less than $0.05 \mathrm{mg} . \mathrm{L}^{-1}$, while values that are greater than $0.2 \mathrm{mg} . \mathrm{L}^{-1}$ are observed in summer and at St 4 ; values between 0.1 and $0.2 \mathrm{mg} . \mathrm{L}^{-1}$ are found in autumn and spring and at St 2 and St3. Moreover, nitrite values ranged from 0.02 to $0.23 \mathrm{mg} . \mathrm{L}^{-1}$; values that are less than $0.1 \mathrm{mg} . \mathrm{L}^{-1}$ were found at $\mathrm{St} 1$ and in winter and values greater than $0.20 \mathrm{mg} . \mathrm{L}^{-1}$ were found at St 2 and St 4 and in summer; whereas the intermediate values are recorded in spring and autumn and at St3.

The comparison between stations by using the nonparametric Kruskal Wallis test revealed significant differences $(p<0.05)$ for the following variables: Melosira (MEL), Surirella (SUR), dissolved oxygen $\left(\mathrm{O}_{2}\right)$, suspended matter $(\mathrm{SM})$, and nutrients $\left(\mathrm{NO}_{2}{ }^{-}\right.$and $\left.\mathrm{PO}_{4}{ }^{3-}\right)$. Concerning the season factor, the Kruskal Wallis test revealed also significant differences for Navicula (NAV) and Nitzschia (NIT) loads as well as for orthophosphates $\left(\mathrm{PO}_{4}{ }^{3-}\right)$, temperature $(\mathrm{T})$, and dissolved oxygen $\left(\mathrm{O}_{2}\right)$. In addition, the post hoc pairwise comparisons of the Dunn's test are presented by boxplots showed in Figure 5 for season factor and Figure 6 for station factor.

\section{Correlation analysis between environmental parameters and Diatoms' density}

The non-parametric spearman correlation analysis is presented in Figure 7 and showed, in the one hand, a significant positive correlation $(p \geq 0.5)$ between Navicula and $\mathrm{T}(r=+0.67)$, Synedra and $\mathrm{pH}(r=+0.53)$, Navicula and Nitzschia $(r=+0.54)$, Thalassiosira and SM $(r=+0.57)$ and Thalassiosira and $\mathrm{NO}_{2}(r=+0.56)$, and on the other hand, a significant negative correlation between Synedra and Nitzschia ( $r=-0.55)$, Synedra and Navicula $(r=-0.65)$, Synedra and T ( $r=-0.50)$, Nitzschia and $\mathrm{pH}(r=-0.57)$, Nitzschia and $\mathrm{O}_{2}(r=-0.62)$, Navicula and $\mathrm{pH}(r=-0.60)$, Thalassiosira and $\mathrm{O}_{2}(r=-0.53)$.

\section{Spatiotemporal variation analysis of the physicochemical and the Diatoms' distribution: Principal component analysis (PCA)}

Generally, the PCA results about the spatiotemporal variation of some biotic and abiotic parameters in Ain Dalia Dam; show a clear structuring for sampling stations and season. In a summarized way, the PCA resulted in two relevant components that accounted for $72.21 \%$ of the spatiotemporal data variance (total inertia). This percentage is relatively high and thus the first plane well represents the Spatiotemporal data variability and the description will stand to these two first axes.

On the one hand, the first PCA axis alone explains $43 \%$ of the total dataset inertia and shows positive correlation with: $\quad \mathrm{NO}_{2}{ }^{-}\left(r=+0.79, \quad \cos ^{2}=0.63\right), \quad \mathrm{PO}_{4}{ }^{3-}(r=+0.71$, $\left.\cos ^{2}=0.51\right)$ and Nitzschia $\left(r=+0.55, \cos ^{2}=0.30\right)$; but it displayed a negative correlation with $\mathrm{O}_{2}\left(r=-0.92, \cos ^{2}=\right.$ $0.85)$ and $\mathrm{pH}\left(r=-0.54, \cos ^{2}=0.29\right)$ (Figure 8.C).

Table 4. Spatiotemporal variations outcomes (Mean $\pm \mathrm{Se}, n=48)$ of temperature $\left(\mathrm{T},{ }^{\circ} \mathrm{C}\right)$, dissolved oxygen $\left(\mathrm{O}_{2}, \%\right)$, $\mathrm{pH}$, suspended matter $\left(\mathrm{SM}\right.$, g. $\left.\mathrm{L}^{-1}\right)$, nitrites $\left(\mathrm{NO}_{2}^{-}, \mathrm{mg} \cdot \mathrm{L}^{-1}\right)$, nitrates $\left(\mathrm{NO}_{3}^{-}, \mathrm{mg} . \mathrm{L}^{-1}\right)$, orthophosphates $\left(\mathrm{PO}_{4}{ }^{3-}, \mathrm{mg} . \mathrm{L}^{-1}\right)$ in Aïn Dalia Dam (Souk Ahras, Algeria)

\begin{tabular}{|c|c|c|c|c|c|c|c|c|}
\hline \multirow{2}{*}{ Parameters } & \multicolumn{4}{|c|}{ Station } & \multicolumn{4}{|c|}{ Season } \\
\hline & St1 & St2 & St3 & St4 & Summer & Autumn & Winter & Spring \\
\hline $\mathrm{T}$ & $19.9 \pm 1.82$ & $17.01 \pm 1.57$ & $17.56 \pm 2.13$ & $16.31 \pm 1.72$ & $24.86 \pm 0.76$ & $18.70 \pm 0.99$ & $10.73 \pm 0.66$ & $15.68 \pm 1.65$ \\
\hline $\mathrm{pH}$ & $7.71 \pm 0.16$ & $7.56 \pm 0.15$ & $7.89 \pm 0.11$ & $7.58 \pm 0.20$ & $07.58 \pm 0.12$ & $7.63 \pm 0.10$ & $7.56 \pm 0.23$ & $7.99 \pm 0.14$ \\
\hline $\mathrm{O}_{2}$ & $73.71 \pm 2.37$ & $34.54 \pm 4.94$ & $54.89 \pm 5.93$ & $39.05 \pm 4.61$ & $34.50 \pm 5.45$ & $47.76 \pm 5.98$ & $66.46 \pm 4.22$ & $53.46 \pm 6.40$ \\
\hline $\mathrm{PO}_{4}^{3-}$ & $0.05 \pm 0.01$ & $0.16 \pm 0.04$ & $0.16 \pm 0.12$ & $0.20 \pm 0.10$ & $0.25 \pm 0.12$ & $0.19 \pm 0.10$ & $0.02 \pm 0.00$ & $0.11 \pm 0.00$ \\
\hline $\mathrm{NO}_{2}^{-}$ & $0.02 \pm 0.01$ & $0.23 \pm 0.09$ & $0.10 \pm 0.05$ & $0.22 \pm 0.03$ & $0.23 \pm 0.09$ & $0.10 \pm 0.04$ & $0.09 \pm 0.03$ & $0.15 \pm 0.05$ \\
\hline SM & $25.57 \pm 2.69$ & $139.22 \pm 51.89$ & $52.88 \pm 4.77$ & $158.42 \pm 38.48$ & $75.52 \pm 13.22$ & $79.17 \pm 12.52$ & $160.40 \pm 65.92$ & $61.04 \pm 10.89$ \\
\hline
\end{tabular}





Figure 5. Seasonal variations in physicochemical and biological parameters in the Aïn Dalia Dam $(n=48)$. Different letters indicate a significant difference among levels of variables $(p<0.05)$. Central box limits show the interquartile range (IQR) with the first (lower box bound) and third (upper box bound) quartiles. Outliers (values outside IQR limits \pm 1.58 times IQR) are indicated by small black points
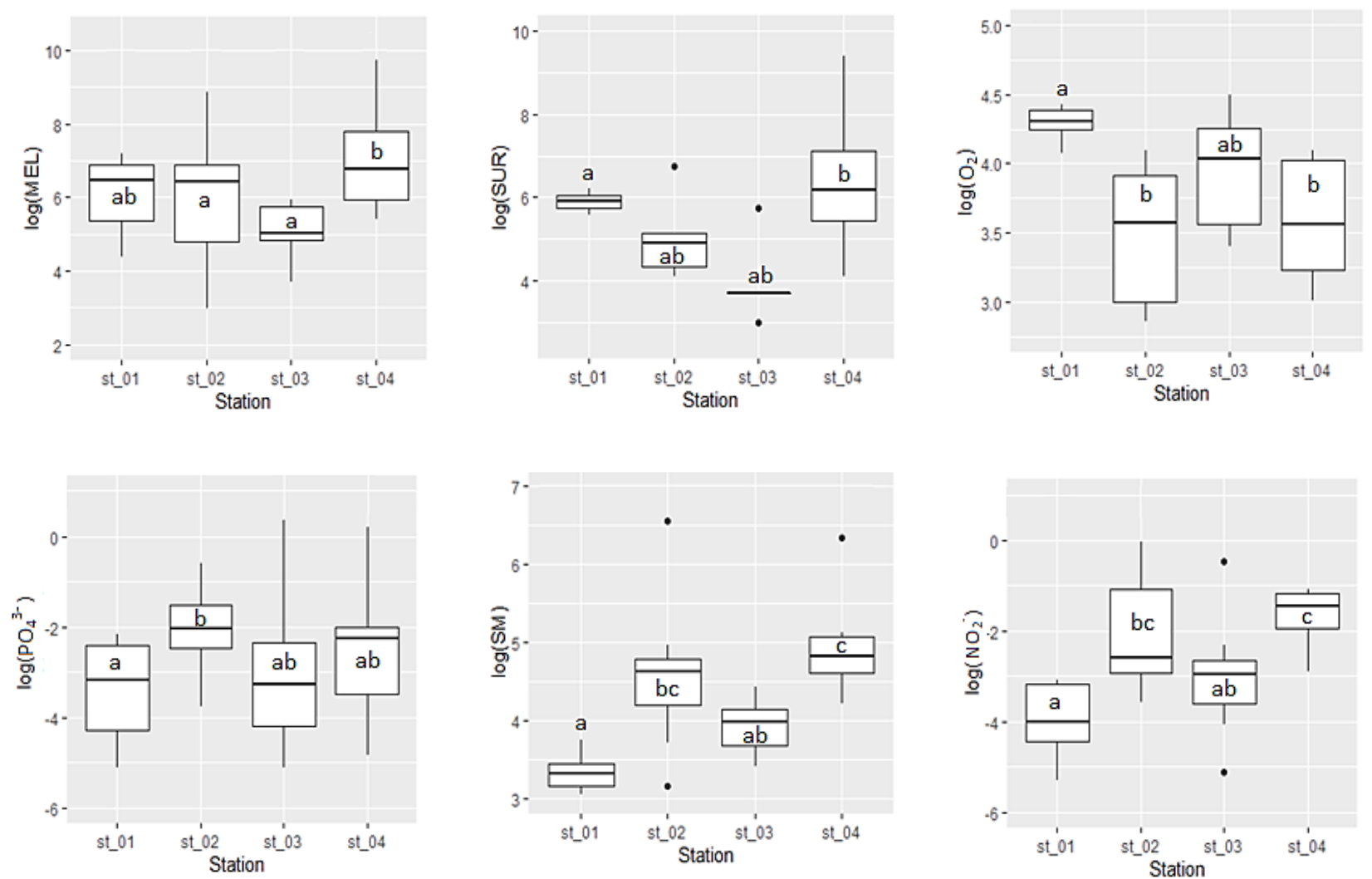

Figure 6. Spatial variations in physicochemical and biological parameters in the Aïn Dalia Dam ( $n=48)$. Different letters indicate a significant difference among levels of variables $(p<0.05)$. Central box limits show the interquartile range (IQR) with the first (lower box bound) and third (upper box bound) quartiles. Outliers (values outside IQR limits \pm 1.58 times IQR) are indicated by small black points 


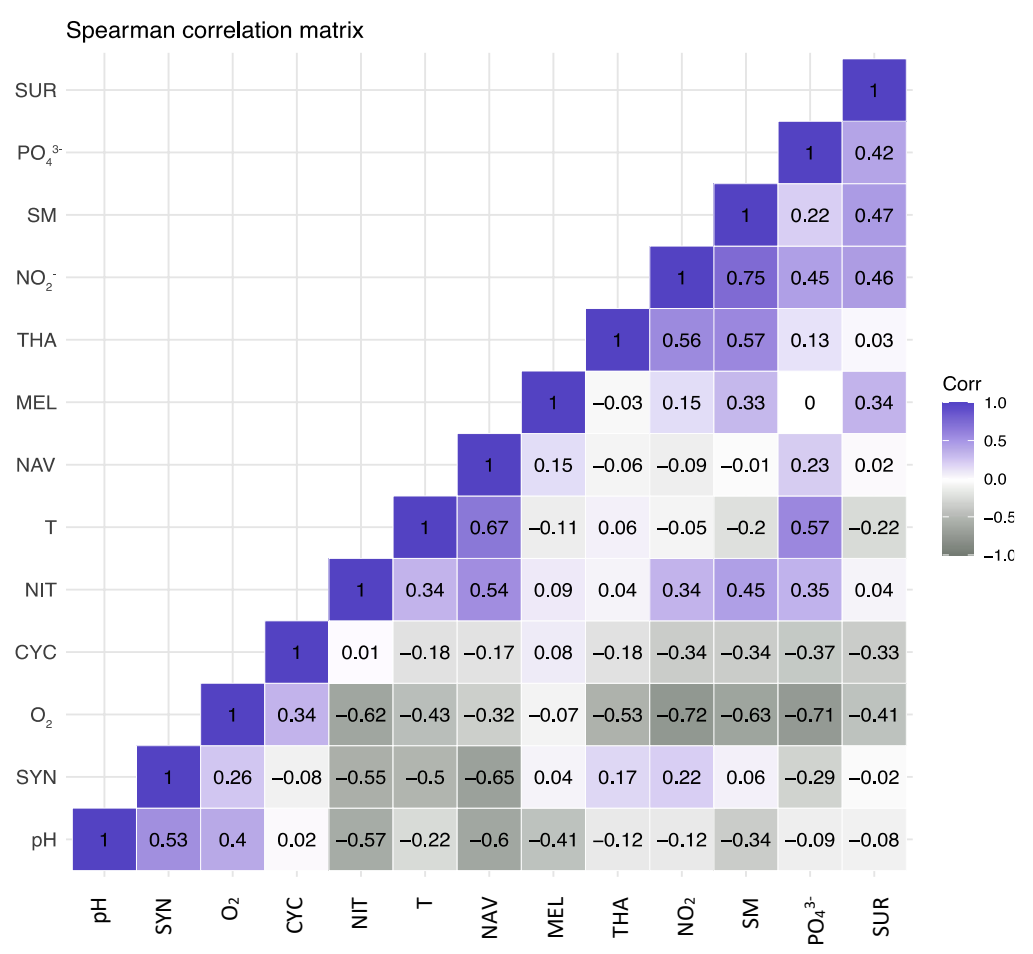

Figure 7. Corrplot of the $r$ Spearman correlation calculated between all the analyzed physicochemical parameters and Diatoms' genera loads. Note: T: temperature, $\mathrm{NO}_{2}{ }^{-}$: nitrites, $\mathrm{O}_{2}$ : dissolved oxygen, $\mathrm{pH}$ : hydrogen potential, $\mathrm{PO}_{4}{ }^{3-}$ : orthophosphates, $\mathrm{SM}$ : suspended matter, CYC: Cyclotella, NAV: Navicula, NIT: Nitzschia, SUR: Surirella, SYN: Synedra, MEL: Melosira, THA: Thalassiosira

This axis explained clearly a distinction between our four sampling stations: St2 and St4 are characterized by fairly high levels of nitrites, and orthophosphates as well the density of Nitzschia genus; while the St1 and the St3 are richly oxygenated with high $\mathrm{pH}$ values and with a dominance of both Cyclotella and Synedra genera (Figures 8.A-B). On the other hand, the second PCA axis explains $29.20 \%$ of the total dataset inertia; it is positively correlated with T $\left(r=+0.76, \cos ^{2}=0.58\right)$ but negatively correlated with SM $\left(r=-0.83, \cos ^{2}=0.69\right)$. This axis reveals a clear seasonal structure, which allows us to distinguish the hottest months from the coldest ones, it opposes the summer season to the winter season with two overlapping seasons (spring and autumn). From Figure 8.B-C, we can conclude that the high levels of suspended matter (SM) were registered in the winter season with a dominance of both Synedra and Thalassiosira genera, in opposition to Navicula genus which could appear in the summer season.

\section{Discussion}

\section{Environmental parameters}

The $\mathrm{pH}$ of the waters of Ain Dalia dam is alkaline. (7.57.9). The highest values of the $\mathrm{pH}$ were observed in St1 and St3 where dissolved oxygen levels are highest; A positive correlation is noted between $\mathrm{pH}$ and dissolved oxygen $(p<0.05)$. Our data were in accordance with those reported by Chabaca et al (2020) at the Lake Oubeira, by Draredje et al (2019) at the Lake Melleh, by Ayad and Kahoul (2016) at the well water in the region of ElHarrouch, by Kahoul and Touhami (2014) on drinking water of the city of Annaba and by Manamani 2007; Agouni 2013 at the Ain El-Dalia dam, for which they report $\mathrm{pH}$ values between 6 and 9. Indeed, this alkalinity could be due to the increase in diatom communities (Seyni 2006), by an increase in oxygen in the water and by the consumption of $\mathrm{CO} 2$ through photosynthesis (Stum and Morgan, 1991; Martin 2004)

The water of stations St 4 and St2 was low in oxygen. The oxygen uptake could explain these low values by the bacteria (Dandelot et al. 2005), which was favored by the increase of urban and industrial wastewaters containing a great quantity of organic matter (Arrignon 1998). A significant negative correlation between dissolved oxygen and $\mathrm{SM}$ and $\mathrm{PO}_{4}{ }^{3-}(p<0.05)$ and a highly significant correlation between dissolved oxygen and $\mathrm{NO}_{2}^{-}(p<0.001)$ were noted.

Both Stations St4 and St2 displayed a high level of pollution in contrast to the rest of the stations (St1 and St3) which exhibited a moderate level of pollution. The St4 and St2 stations have the highest $\mathrm{SM}, \mathrm{NO}_{2}{ }^{-}$and $\mathrm{PO}_{4}{ }^{3}$ levels because their water comes from municipal and treatment plant discharges. These data agree with those reported from the Oued of Madjerda by Nait Merzoug (2012), who confirmed an adverse impact on the physicochemical characteristics. This implies that the water of this river has a major pollution problem.

According to Savary (2003), the fluctuations of the suspended solids indicated a certain irregularity both at spatial and temporal levels, according to the season, rainfall, and discharges. The evolution of the nitrogen contents showed a temporal difference. The low values were dependent on important nitrification (Abba et al. 2008) and a strong absorption (Issola et al. 2008). 



Figure 8. Principal component analysis carried out on all variables (physicochemical and Diatoms' loads' parameters) for 'season' and 'station' factors at Aïn Dalia Dam (Dim 1: $43 \%$ and Dim 2: 29.2\%): A-B. Scatter diagrams representing the projections of the studied stations and seasons respectively; C. Circle of correlations between the first two principal components analyzed all the analyzed data variables. $\mathrm{NO}_{2}^{-}$: nitrites, $\mathrm{O}_{2}$ : dissolved oxygen, $\mathrm{pH}$ : hydrogen potential, $\mathrm{PO}_{4^{3-}}$ : orthophosphates, $\mathrm{SM}$ : suspended matter, T: temperature, CYC: Cyclotella, NAV: Navicula, NIT: Nitzschia, SUR: Surirella, SYN: Synedra, MEL: Melosira, THA: Thalassiosira (the seven Diatoms' loads were used as supplementary variables and are shown as blue arrows)
Taking into account the average annual dissolved oxygen, nitrate, and phosphate contents recorded in the 4 stations, we can consider the waters of stations St1 and St3 as class II (presenting moderate pollution and therefore of mean quality) and those of stations St 2 and St 4 as class III (presenting significant pollution and therefore of very low quality). In terms of SM content, the dam waters would be excessively polluted and would thus be part of class IV (ANRH. 2000).

\section{Composition of diatom communities}

The present study carried out on diatomic settlement in Aïn Dalia dam promotes inventing 72 species distributed in 31 genera. These findings, particularly those of some taxa carried out in El-Kala region (north-east Algeria) were previously reported, including those in Chelif river (AlAsadi et al. 2006), the black Lake (Amri 2008), Kebir river (Chaïb et al. 2011), Oubeira and El Malah Lake (Draredja 2007; El-Haouati et al. 2015; Draredja 2019; Draredja et al. 2019a, b), Oubeira Lake (Djabourabi et al. 2014 2017; Chabaca et al. 2020). Furthermore, some other data regarding these species were reported from previous studies carried out in Algeria; in the Gulf of Annaba (northeastern of Algeria) (Ounissi and Frehi 1999), in Chiffa Blida river (Hamaidi-Chergui et al. 2013), in Sidi-Yacoub dam (Houari 2009) and in some of watercourse of Oranie (Nehar et al. 2015; Nehar 2016).

Diversity is a crucial ecological subject, generally perceived as the best indicator of the ecosystem health status (Magurran 1988). In this study, the maximum richness was observed in autumn $\left(\mathrm{S}=57\right.$ species, $\mathrm{H}^{\prime}=3$, $\mathrm{D}=0.926, \mathrm{E}=0.742)$ and summer, $\left(\mathrm{S}=56\right.$ species, $\mathrm{H}^{\prime}=2.999$, $\mathrm{D}=0.926, \mathrm{E}=0.742)$. Regarding spatial specific richness, the highest values of ecological indices are recorded in station St4 ( $\mathrm{S}=52$ species; $\mathrm{H}^{\prime}=3$ and $\left.\mathrm{D}=0.9260 ; \mathrm{E}>076\right)$. in terms of proportions in relation to the overall density of the diatoms collected in Aïn Dalia dam, the diatoms show seasonal densities that evolve in decreasing order according to autumn $(43 \%) \geq$ Winter $(25 \%) \geq$ Summer $(18 \%) \geq$ Spring (14\%). The dominance index (DI) estimation of the 31 identified genera from waters of Aïn Dalia dam, revealed the dominance of Cyclotella ( $\mathrm{D}=18.97 \%)$, Melosira ( $\mathrm{D}=13.30 \%)$, Thalassiosira $(\mathrm{D}=13.07 \%)$, Nitzschia $(\mathrm{D}=8.51 \%)$, Navicula $(\mathrm{D}=8.14 \%)$ Surirella $(\mathrm{D}$ $=5.38 \%)$ and Synedra $(\mathrm{D}=5.34 \%)$.

However, the study performed by Nehar (2016) has revealed that the results of settlement structure from ElHammam and Chelif rivers (North-est Algeria) provided generally, low mean values. On the other hand, Draredja et al. (2019a) reported that the diversity of populations of diatoms in the Mellah is up to 4.56 bits.cell $^{-1}$ and with a of regularity of 0.98 , and thus suggesting populations of structured diatoms for a single period of the year (winter and late spring). However, the rest of the cycle is characterized by unstable species composition. Chabaca et al. (2020) in Oubeira Lake showed that the genera Cymbella and Navicula dominated the two stations of Oubeïra Lake.

In the Reghaia dam lake, El Haouati et al. (2015) report the presence of 24 species belonging to 13 genera; this 
diversity increased during the spring and autumn periods. In Reghaia Lake, the abundance of taxa study showed that the genus Cyclotella occupied an important place in the diatom community, with more than $50 \%$ of the diatoms present in winter and summer; during the spring and autumn periods, they noted the dominance of Stephanodiscus and Navicula. In the Beni Haroun dam, the number of species is 14 for 9 genera; in this water body, the most representative genera of the group of Bascillariophyceae are Cyclotella, Navicula and Nitzchia (Kherief Nacereddine et al. 2018). Of all the species described in the three water bodies, only the species Stephanodiscus sp. is found exclusively in Reghaia. However, we note that the Cyclotella genus is dominant in Aïn Dalia as well as in Reghaia and Beni Haroun. According to Airill et al. (2016), in shallow nutrient-rich turbid water diatoms like Cyclotella, Stephanodiscus, Asterionella, Diatoma, Fragilaria, Navicula, Nitzschia, Melosira and Synedra exist in higher density. Members of Bacillariophyceae like Navicula, Nitzschia, and Synedra species can tolerate pollution and be used as sewage pollution indicators (Shekhar et al. 2008).

According to Håkansson (2002), the genus Cyclotella often dominates species assemblages in paleolimnology, particularly in the circum Mediterranean region, and can cause difficulties or loss of information in paleoenvironmental reconstructions due to the ongoing taxonomic uncertainty in this group. In the waters of the Ain Dalia dam, the genus Cyclotella shows the highest proportions in stations St1 and St3 (respectively 58\%, 20\% and $32 \%$ of the overall seasonal abundance) and therefore seems to be able to accommodate strong variations in oxygen saturation rates $(73 \%, 35 \%$ and $55 \%$ respectively in St1, St 2 and St3) and $\mathrm{T}^{\circ}$ between 17 and $19^{\circ} \mathrm{C}$. Cremer and Wagner (2003) suggested that the Cyclotella ocellata complex must comprise several different species or ecological groups, exhibiting contrasting ecological preferences for nutrient status, which may relate to the biogeographic region in which they grow. It also occurs in slow-flowing rivers as plankton or periphyton (Krammer and Lange-Bertalot 1991; Ehrlich 1995; Houk et al. 2010). According to Loudiki (1990), this genus presents a recognizable heliophilous character and it develops in an optimal way when the temperature is around $20^{\circ} \mathrm{C}$. Species of the genus Cyclotella represent an important component of the diatom community of eutrophic lakes (Schelegel and Scheffler 1999) and they were already reported in the waterways of North Africa (Fawzi et al. 2002; Chaïb and Tison-Rosebery 2012).

Excepting autumn and the St4 station where it registers the lowest proportions, the Thalassiosira genus, like Cyclotella, seems to tolerate various environmental conditions. Species of the genus Thalassiosira seem to have preferences for SM and nitrite-rich waters $(r=0.57$ and $\mathrm{r}=0.56$ respectively) but not for oxygen loads ( $\mathrm{r}=$ $0.53)$.

In terms of densities, Melosira genus accounts for 35\% of the overall density recorded in station St4 (first place), $15 \%$ in station St 1 (second place), and $14 \%$ in station St2 (third place); this genus is mainly present in autumn and winter and seems to prefer SM-rich waters with a fairly low pH. According to Kilham et al. (1986) Melosira species are generally opportunistic organisms that are adapted to the non-equilibrium conditions that exist when wind-induced mixing permits them to enter the plankton. The ecology of meroplanktonic Melosira species contrasts markedly with that of euplanktonic species, such as Stephanodiscus sp., planktonic Nitzschia sp. and Synedra sp. (Kilham et al. 1986).

The genus Nitzschia's relatively strong presence is noted in warm periods (autumn and summer) and in the St4 station where it seems to seek waters with relatively high $\mathrm{SM}, \mathrm{NO}_{2}{ }^{-}$and $\mathrm{PO}_{4}{ }^{3-}$ contents and low dissolved oxygen $(\mathrm{r}=-$ $0.62)$.

The species of the genus Navicula are present in all the stations in proportions varying from 7 to $15 \%$; the genus Navicula shows preferences for the summer period when high temperatures are favorable $(r=0.67)$ and for moderately polluted environments such as stations $\mathrm{St} 1$ and St3 where it records scores of the order of 11 and $15 \%$ respectively.

The genus Synedra shows its highest score in the St3 plant and especially in spring; the latter seems to prefer the alkaline waters of the St3 station $(\mathrm{r}=0.53)$ and spring when the $\mathrm{pH}$ is quite high $(\mathrm{r}=0.53)$ and temperatures are quite low $(\mathrm{r}=-0.50)$.

The genus Surirella shows its highest score (18\%) in the St4 station, considered to be the most polluted area of the water body; The latter shows the highest concentrations of $\mathrm{MS}, \mathrm{NO}_{2}{ }^{-}$and $\mathrm{PO}_{4}{ }^{3-}$ that Surirella is looking for to develop, although the results of the Spearman test do not reveal the existence of significant correlations between all these parameters. Besides, Surirella species are sometimes common in acid waters in high-altitude lakes and peats and they develop in waters moderately rich in organic matter, but they are more common in waters with high temperatures, alkaline $\mathrm{pH}$ values, and relatively high conductivity (Sala et al. 2013).

The results of Hamaidi-Chergui et al. (2013) showed that the algal flora (diatoms) found in the Chiffa water river was dominated by the genera Synedra and Melosira. In the same context, the published work of Sidi YakoubBezzeghoud et al. (2014), in the seminar of ADLAF, proved the presence of 66 species and a variety of 23 genera in Rhiou river and El-Malah river (basin of low Chelif and basin of Tafna), in which the species Pénnatophycidées are dominating with 64 species against 2 species of Centriphycidées. Similarly, the authors have shown the dominance of genus Diatoma with a rate of $42.37 \%$ as compared with the genus Nitzschia (17.5\%) found at the Rhiou river, since the genera Nitzschia et Navicula are predominant in Malah river, along with rates of $63.87 \%$ and $18.5 \%$ respectively. However, the study of Draredja et al. (2019a), in the Melleh lagoon, indicates that the dominant genus is Nitzschia. The study of Chabaca et al. (2020), in the Oubeira lake, indicated that the genera Cyclotella and Nitzschia dominated the lake. 


\section{Structure of diatom flora in relation to water quality}

The ACP analysis carried out with 6 environmental variables and 7 diatom dominant genera, highlighted the links between the environmental characteristics of the Ain Dalia dam and the different diatom dominant genera. Based on the two-first axes of the ACP, representing $72.21 \%$ of the variance, this analysis revealed that the phosphate, nitrite, $\mathrm{pH}$, dissolved oxygen, temperature, and suspender matter significantly explained the variability diatom communities.

The first axis (43\% of the variance) opposes nitrites, orthophosphates, and Nitzschia to dissolved oxygen and $\mathrm{pH}$. This axis shows a clear difference between the group consisting of two stations St2 and St4, which is characterized by fairly high levels of nitrite, and orthophosphates as well the density of genus Nitzschia; and the group consisting of two other stations St1 and St3, which are richly oxygenated with high values of $\mathrm{pH}$.

PCA axis II explains $29.20 \%$ of the total variability; it correlates positively with temperature and negatively with suspended solids. This axis shows a fairly clear temporal structure that allows us to form two groups: one including summer, autumn, and spring, which show relatively high Temperature and relatively low suspended solids concentrations, and the other including only winter, when temperatures are low and suspended solids concentrations are high.

According to Kelly (2003), the distribution of diatoms is mainly explained by phosphorus; nutrients, primarily nitrogen and phosphorus, constitute one of the most important factors affecting the structure of the diatoms communities. Nehar (2016) has reported that distribution of diatoms in the aquatic environment is influenced by several biotic and abiotic factors, including substrate, $\mathrm{pH}$, temperature and speed of water, chatter, pollution by organic and mineral matters. Likewise, El-Haouati (2015) has evidenced the links between the environmental characteristics of Reghaia Lake and the different diatomic species. Moreover, Chaïb et al. (2011) and Chaïb and Tison-Rosebery (2012) have found a correlation between the environmental factors and the diatomic species through using Canonical correspondence analysis (CCA) and coinertia analysis (CIA).

The results of the study show that (i) the diatomic flora includes 72 species, the maximum richness was observed in summer and autumn (57 and 56 species respectively) and in station St4 (52 species); (ii) more than $40 \%$ of the overall density is encountered in station St 4 and the fall period; (iii) Among the dominant genera, Cyclotella, Thalassiosira, Synedra and Navicula frequent moderately polluted waters and Nitzschia, Melosira and Surirella significantly polluted waters. (iv) The waters of the Aïn Dalia dam are moderately (St1 and St3) to significantly polluted (St2 and St4), this provides lower quality habitats for the development and survival of diatoms. These microorganisms play a very important role for the biomonitoring of aquatic ecosystems as a bio-indicator of water quality. The need to protect these habitats from pollution and destruction is urgent. It is important to highlight the direct influence of nutrients $\left(\mathrm{NO}_{2}{ }^{-}\right.$and $\left.\mathrm{PO}_{4}{ }^{3-}\right)$,
SM, temperature, and dissolved oxygen in the distribution of diatoms.

\section{REFERENCES}

Abba E, Nassali H, benabid M, El Ayadi R, El Ibaoui H. 2008. Contribution à l'étude physicochimique de l'écosystème lacustre Dayet Aoua au Maroc. Afr J Sci Tech 4 (2): 306-317. [French]

Afonina E Yu, Tashlykova N A, Kuklin A P, Tsybekmitova G Ts. 2020. Environmental features and dynamics of plankton communities in a mountain glacial moraine lake (Baikal Lake Basin, Russia). Nat Conserv Res 5 (3): 23-36. DOI: 10.24189/ncr.2020.025

Agouni M. 2013. Caractérisation physico-chimiques et étude des Cyanobactéries dans le barrage d'Ain El-Dalia (Région de Souk Ahras) [Thesis]. Mohammed Cherif Messaadia University, Souk Ahras, Algeria. [French]

Airill LM, Querijero BL, Ching JA. 2016. Phytoplankton community in aquaculture and non-aquaculture sites of Taal lake, Batangas. Philippines J Exp Biol Agric Sci 4 (1): 66-73.

Al-Asadi MS, Randerson P, Benson-Evans K. 2006. Phytoplankton population dynamics in three west Algerian rivers: I-The river Cheliff and its tributary, the river mina. Marina Mesopotamica Online 1: 4872.

Amri S. 2008. Dynamique mensuelle du phytoplancton dans le lac Oubeira et le lac Noir, Parc National EL-Kala [Thesis]. University of Annaba, Algeria. [French]

ANBT. 2015. Agence Nationale des Barrages et Transferts, Algérie/ National Agency of Dams and Transfers, Algeria. [French]

ANRH. 2000. Données pluviométriques. Document interne. Alger, Algérie/ Rainfall data. Internal document. Algiers Algeria. [French]

Arrignon J. 1998. Aménagement écologique et piscicole des eaux douces. Cinquième éd., Gauthier-Villars, Paris. [French]

Baudrimont R. 1973. Recherche sur les diatomées des eaux continentales de l'Algérie, écologie et paléoécologie. [Thesis]. Université de Bordeaux, Talence, France. [French]

Bey MY, Ector L. 2013. Atlas des diatomées des cours d'eau de la région Rhône-Alpes. (1). Centriques, Monoraphidees. (2). Araphidees, Brachyraphidees. (3). Naviculacees: Naviculoidees. (4). Naviculacees: Naviculoidees. (5). Naviculacees: Cymbelloidees, Gomphonematoidees. (6). Bacillariacees, Rhopalodiacees, Surirellacees. Direction regionale de l'Environnement, de l'Amenagement et du Logement Rhône-Alpes, Lyon. [French]

Chabaca H, Marniche F, Tadjine A. 2020. Diatoms diversity in Oubeïra Lake, northeastern Algeria. Biodiversity J 11 (2): 573-580. DOI: 10.31396/Biodiv.Jour.2020.11.2.573.580

Chaïb N, Alfarhan AH, Al-Rasheid KAS, Samraoui B. 2011. Environmental determinants of diatom assemblages along a North African wadi, the Kebir-East, northeast Algeria. Intl J Limnol 70 (1): 33-40. DOI: 10.3274/JL11-70-1-06.

Chaïb N, Tison-Rosebery J. 2012. Évaluation de la qualité de l'eau et application de l'indice de diatomées biologiques dans l'oued KebirEast, en Algérie. Afr J Aquat Sci 37 (1): 59-69. DOI: 10.2989/16085914.2011.636898.

Cremer H, Wagner B. 2003. The diatom flora in the ultra-oligotrophic El'gygytgyn, Chukotka. Polar Biol 26 (2): 105-114. DOI: 10.1007/s00300-002-0445-0.

Dandelot S, Matheron R, Le Petit J, Verlaque R, Cazaubon A. 2005. Temporal variations of physicochemical and microbiological parameters in three freshwater ecosystems (southeastern France) invaded by Ludwigia spp. C R Biol 328 (10-11): 991-999. DOI: 10.1016/j.crvi.2005.09.007.

Djabourabi A, Sehili N, Boussadia M, Samar F, Bensouilah M. 2014. Fluctuations des paramètres physico chimiques et des communautés phytoplanctoniques dans le lac Oubeira (Nord-Est Algérien). Eur J Res 118 (2): 183-196.

Djabourabi A, Touati H, Sehili N, Boussadia M I, Bensouilah M. 2017. Study of the physicochemical parameters of water and phytoplankton in Lake Tonga (wetland of the national park of El Kala, Northeast of Algeria). Intl J Biosci 11 (3): 213-226. DOI:10.12692/ijb/11.3.213226.

Draredja A, Barour C, Frihi H, Boualleg C, Gofart A, Abadie E, Laabir M. 2019 b. Seasonal variations of phytoplankton community in relation to environmental factors in a protected meso-oligotrophic southern 
Mediterranean marine ecosystem (Mellah lagoon, Algeria) with an emphasis of HAB species. Environ Monit Assess 191: 603. DOI 10.1007/s10661-019-7708-5.

Draredja A, Barour C, Frihi H, Boualleg C, Laabir M. 2019a. Diatoms diversity and dynamics in a southern Mediterranean lagoon (Mellah, Algeria). Biodiversity J 10 (2): 127-140. DOI: 10.31396/Biodiv.Jour 10.2.127.140.

Draredja A. 2019. Phytoplancton de la lagune Mellah: mise en évidence des espèces potentiellement toxiques [Thesis]. Mohammed Cherif Messaadia University, Souk Ahras, Algeria. [French]

Draredja B. 2007. Structure et fonctionnement d'un milieu lagunaire Méditerranéen: lagune mellah (el-kala, Algérie nord-est) [Thesis]. University of Annaba, Algeria. [French]

Ehrlich A. 1995. Atlas of the inland-water diatom flora of Israel; Flora Palaestina, The Geological Survey of Israel. The Israel Academy of Sciences y Humanities. Israel.

El-Haouati H, Arab A, Tudesque L, Lek S, Samraoui B. 2015. Study of the Diatoms of Reghaia Lake, Northern Algeria. Rev Ecol 70 (1): 114

Fawzi B, Loudiki M, Oubraim S, Sabour B, Chlaida M. 2002. Impact of wastewater effluent on the diatom assemblages structure of a brackish small stream: Oued Hassar (Morocco). Limnology 32: 54-65. DOI: 10.1016/S0075-9511(02)80017-2.

Hall RI, Smol JP, Smol JP. 1999. Diatoms as indicators of lake eutrophication. Smol JP, Stoermer EF (eds.). The Diatoms: Applications for the Environmental and Earth Sciences, 2 ed, Cambridge University Press, Canada. DOI: 10.1017/CBO9780511763175.008

Hamaidi-Chergui F, Brahim Errahmani M, Benouakli F, Hamaidi MS 2013. Preliminary study on physicochemical parameters and phytoplankton of Chiffa River (Blida, Algeria). J Ecosyst 2013: 148793. DOI: $10.1155 / 2013 / 148793$.

Hankansson H. 2002. A compilation and evaluation of species in the general Stephanodiscus, Cyclotephanos and Cyclotella with a new genus in the family Stephanodiscaceae. Diatom Res 17 (1): 1-139. DOI: 10.1080/0269249X.2002.9705534.

Houk V, Klee R, Tanaka H. 2010. Atlas of freshwater centric diatoms with a brief key and descriptions Part III. Stephanodiscaceae A. Cyclotella, Tertiarius, Discotella. Fottea 10 (Suppl.): 1-498.

Issola Y, Kouassi AM, Dongui BK, Biemi J. 2008. Caractéristiques physico-chimiques d'une lagune côtière tropicale: lagune de Fresco (Côte d'Ivoire). Afr J Sci Tech 4 (3): 368-393.

Kahoul M, Touhami M. 2014. Evaluation de la qualité physico-chimique des eaux de consommation de la ville d'Annaba (Algérie). Larhyss J 19: $129-138$.

Kelly MG, Cazaubon A, Coring E, Dell'Uomo A, Ector L, Goldsmith B, Kwandrans J et al. 1998. Recommendations for the routine sampling of diatoms for water quality assessments in Europe. J Appl Phycol 10 (2): 215. DOI: $10.1023 / \mathrm{A}: 1008033201227$

Kelly MG. 2003. Short-term dynamics of diatoms in an upland stream and implications for monitoring eutrophication. Environ Pollut 125 (2) 117-122. DOI: 10.1016/S0269-7491(03)00075-7.

Khereif Nacereddine S, Djeddi H, Benayache Y, Afri-Mehennaoui FZ. 1857. Dynamique des éléments nutritifs et du phytoplancton dans le Barrage Béni-Haroun dans l'est algérien. Eur Sci J 14 (12): 7431 DOI: 10.19044/esj.2018.v14n12p111.

Kilham P, Kilham SS, Hecky RE. 1986. Hypothesized resource relationships among African planktonic diatoms. Limnol Oceanogr 31 (6): 1169-1181. DOI: 10.4319/lo.1986.31.6.1169.

Krammer K, Lange-Bertalot H. 1991. Bacillariophyceae, 3. Teil Centrales, Fragilariaceae, Eunotiaceae. In: Süßwasserflora von Mitteleuropa (H. Ettl, J. Gerloff, H. Heynig \& D. Mollenhauer, eds), Band 2/3, Gustav Fischer Verlag, Stuttgart, New York.

Loudiki M. 1990. Etude limnologique d'un hydrosystème récemment aménagé dans la région de Marrakec (Maroc). Apports du bassin versant, hydrochimie, algues et macrophytes. [Thesis]. Aix Marseille III, France. [French]

Manamani R. 2007. Niveau trophique et efflorescences des cyanobactéries dans le barrage d'Ain Dalia (Souk Ahras) [Thesis]. University of Annaba, Algeria. [French]

Mc Cormick PV, Stevenson RJ. 1998. Periphyton as a tool for ecological assessment and management in the Florida Everglades. J Phycol 34 (5): 726-733. DOI: 10.1046/j.1529-8817.1998.340726.x.

Nait Merzoug A, Merazig H. 2012. Water pollution of Oued Medjerda in Algerian Souk Ahras Region. Water Qual Monit Assess 527-540. DOI: $10.5772 / 34390$
Negadi M, Hassani A, Hammou MA, Dahmani W, Miara MD Kharytonov M, Zhukov O. 2018. Diversity of Diatom epilithons and quality of water from the subbasin of Oued Mina (district of Tiaret, Algeria). Ukr J Ecol 8 (1): 103-117. DOI: 10. 15421/2018_194.

Nehar B, Blanco S, Hadjadj Aoul S. 2015. Diversity \& ecology of diatoms in northwest of Algeria: Case of El-Hammam Stream and estuary of Cheliff River. Appl Ecol Environ Res 13 (1): 37-52.

Nehar B. 2016. Contribution à l'Etude des Diatomées Benthiques de quelques cours d'eau de l'Oranie: Taxonomie et Ecologie [Thesis]. University of Oran I, Algeria. [French]

Ngansoumana B. 2006. La communauté phytoplanctonique du lac Guiers (Sénégal): types d'associations fonctionnelles et approches expérimentales des facteurs de régulation. [Thesis]. Cheikh Anta Diop University of Dakar, Senegal. [French]

Ounissi M, Frehi H. 1999. Variabilité du microphytoplancton et des Tintinidés (Protozoaires ciliés) d'un secteur eutrophe du golfe d'Annaba (Méditerranée Sud-occidentale). Cah Biol Mar 40: 141153.

Pan Y, Stevenson RJ, Hill BH, Herlihy AT, Collins GB. 1996. Using diatoms as indicators of ecological conditions in lotic systems: a regional assessment. J North Am Benthol Soc 15 (4): 481-495. DOI: 10.1016/j.scitotenv.2021.147410.

Peeters V, Ector L. 2017. Atlas des diatomées des cours d'eau du territoire bourguignon. Volume I: Centriques, Araphidées. Dijon: Direction Régionale de l'Environnement, de l'Aménagement et du Logement Bourgogne-Franche-Comté. [French]

Peeters V, Ector L. 2018. Atlas des diatomées des cours d'eau du territoire bourguignon. Volume II: Monoraphidées, Brachyraphidées. Direction Régionale de l'Environnement, de l'Aménagement et du Logement Bourgogne-Franche-Comté. [French]

Renberg I, Hellberg T. 1982. The pH history of lakes in southwestern Sweden, as calculated from the subfossil diatom flora of the sediments. Ambio 11 (1): 30-33.

Ruhland K, Paterson A. M, Smol JP. 2008. Hemispheric-scale patterns of climate-related shifts in planktonic diatoms from North American and European lakes. Glob Chang Biol 14 (11): 2740-2754. DOI: 10.1111/j.1365-2486.2008.01670.x.

Sala SE, Ramírez JJ, Vouilloud AA, Plata-Díaz Y. 2013. Surirella antioquiensis sp. nov. et $S$. rafaelii sp. nov. (Bacillariophyta) de Colombie. Acta Nova 6 (1-2): 17-35.

Savary P. 2003. Guide des analyses de la qualité de l'eau. Edition technique cite. [French]

Schlegel I, Scheffler W. 199. Seasonal development and morphological variability of Cyclotella ocellata (Bacillariophyceae) in the eutrophic Lake Dagow (Germany). Intl Rev Hydrobiol 84 (5): 469-478. DOI: 10.1002/iroh.199900041.

Seyni S. 2006. Contrôle environnemental de la production primaire du lac de Guiers au Nord du Sénégal [Thesis]. Université Cheikh Anta Diop de Dakar, Sénégal. [French]

Shekhar TS, Kiran BR, Puttaiah ET, Shivaraj Y, Mahadevan KM. 2008. Phytoplankton as index of water quality with reference to industrial pollution. J Environ Biol 29 (2): 233.

Sidi Yakoub-Bezzeghoud B, Mansour B, Reguig L. 2014. Inventaire diatomique d'oued Rhiou afflluent d'oued Chélif et d'oued El Malah affluent de l'oued Tana., nord-ouest de l'Algérie. 33rd Symposium of 1 Association of Diatomistos of French Language, Clermont-Ferrand. [French]

Skála I. 2015. Zooplankton community composition of high mountain lakes in the Tatra Mts., the Alps in North Tyrol, and Scotland: relationship to $\mathrm{pH}$, depth, organic carbon, and chlorophyll-a concentration. Acta Musei Silesiae, Scientiae Naturales 64(2): 175189. DOI: $10.1515 /$ cszma-2015-0025

Sládeček V. 1986. Diatoms as indicators of organic pollution. Acta Hydroch Hydrob 14 (5): 555-566. DOI: 10.1002/aheh.19860140519.

Stum W, Morgan J J. 1991. Aquatique Chemistry. An Introduction Emphasizing Chemical Equilibria in Natural Waters. $2^{\text {nd }}$ ed. John Wiley \& Sons Inc., New York.

Voutilainen A, Jurvelius J, Lilja J, Viljanen M, Rahkola-Sorsa M. 2016. Associating spatial patterns of zooplankton abundance with water temperature, depth, planktivorous fish and chlorophyll. Boreal Environ Res 21 (1-2): 101-114.

Zampella RA, Laidig KJ, Lowe RL. 2007. Distribution of diatoms in relation to land use and $\mathrm{pH}$ in blackwater coastal plain streams. J Environ Manag 39 (3): 369-384. DOI: 10.1007/s00267-006-0041-0. 